\title{
COVID-19 Pandemisinde Elektif Cerrahi Uygulanacak Hastaların Preoperatif Anksiyete Düzeylerinin Değerlendirilmesi
}

\author{
Ayşe Neslihan BALKAYA, Ümran KARACA, Canan YILMAZ, Filiz ATA
}

SBÜ Bursa Yüksek İhtisas Eğitim ve Araştırma Hastanesi, Anesteziyoloji ve Reanimasyon Kliniği, Bursa.

\begin{abstract}
ÖZET
COVID-19 önlemleri alınarak elektif cerrahilerin yeniden başlatıldığı pandemi sürecinde elektif cerrahi uygulanacak hastaların preoperatif anksiyete düzeylerinin ve anksiyete seviyelerini etkileyen faktörlerin değerlendirilmesi amaçlandı. 18-75 yaş grubu elektif cerrahi uygulanacak 450 hasta dahil edildi. Yazılı onamları alınan hastalar preoperatif dönemde değerlendirildi. Demografik verileri, eğitim durumu, medikal geçmişi, anestezi ve cerrahi deneyimleri sorgulandı. COVID-19 hakkında soruların olduğu anket formu ile yirmişer maddelik durumluk ve sürekli kaygı ölçeklerinden oluşan Spielberger Durumluk-Sürekli Anksiyete Ölçeği (STAI) hastalar tarafindan dolduruldu. Durumluk (STAII) ve sürekli (STAI-II) kaygı ölçeklerinde büyük puan yüksek anksiyete seviyesini, küçük puan ise düşük anksiyete seviyesini belirtir. $49.26 \pm 15.51$ yaş ortalaması olan hastaların ortalama anksiyete düzeyi STAI-I'de 41.46 \pm 8.43 , STAI-II'de $37.79 \pm 9.73$ olarak bulundu. Opere edilen kliniklere göre hastaların STAI-I puanları orta düzeyde anksiyete, STAI-II puanları ise hafif düzeyde anksiyete ile uyumluydu. Hastaların yaşı ile STAI-I arasında negatif yönde korelasyon görüldü $(\mathrm{r}=-0.52$, $\mathrm{p}=0.136)$, STAI-II'de ise yaş ile pozitif korelasyon saptandı $(\mathrm{r}=0.22$, $\mathrm{p}=0.321$ ). Cinsiyet, eğitim durumu, geçirilmiş ameliyat öyküsü ve anestezi deneyimi açısından değerlendirildiğinde preoperatif STAI-I ve II puanlarında farklılık saptanmadı. COVID-19 pandemisi hakkında yeterli bilgi sahibi olmadığını düşünen hastaların (\%17,6) STAI-I ve STAI-II puanları anlamlı yüksekti ( $\mathrm{p}=0.000, \mathrm{p}=0.001)$. Ailesinde geçirilmiş COVID-19 enfeksiyonu bulunan hastaların STAI-I ve II puanları ile diğer hastaların puanları benzerdi $(\mathrm{p}=0.76, \mathrm{p}=0.91)$. Hastane yatışında COVID-19 ile enfekte olma tedirginliği bulunan hastaların (287 hasta, \%63.8) STAI-I puanı hastanede COVID-19'a yakalanmaktan korkmayanlara (163 hasta, \%36.2) göre yüksek bulundu ( $\mathrm{p}=0.05)$. Postoperatif dönemde hastane yatışı sırasında COVID-19 ile enfekte olan hasta olmadı. Elektif cerrahi geçirecek hastalarda COVID-19 pandemisinde preoperatif anksiyete düzeyleri artmıştır. Preoperatif dönemde hastalara COVID-19 ile ilgili rutin bilgilendirme yapılmasının ve alınacak önlemlerden bahsedilmesinin anksiyete düzeyini azaltmada faydalı olacağı düşüncesindeyiz
\end{abstract}

Anahtar Kelimeler: COVID-19. Pandemi. Preoperatif anksiyete. STAI.

Evaluation of Preoperative Anxiety Levels of Patients Undergoing Elective Surgery in COVID-19 Pandemic

\begin{abstract}
We aimed to evaluate the pre-operative anxiety levels of patients and the factors affecting their anxiety levels who will undergo elective surgery during the pandemic process in which elective surgeries are restarted by taking COVID-19 precautions. 450 patients between 18-75 years old, will undergo elective surgery were included in the study. Patients, whose written consents were obtained, were evaluated in the preoperative period. The demographic data, educational status, medical history, anesthesia and surgical experiences of the patients were questioned. A questionnaire containing questions about COVID-19 and the Spielberger State-Trait Anxiety Inventory (STAI) consisting of twenty-item state and trait anxiety scales were filled in by the patients. On the state (STAI-I) and trait (STAI-II) anxiety scales, a large score indicates a high level of anxiety, and a small score indicates a low level of anxiety. The average anxiety level of the patients with a mean age of $49.26 \pm 15.51$ years was found as $41.46 \pm 8.43$ in STAI-I and $37.79 \pm 9.73$ in STAI-II. According to the type of operation, STAI-I scores of the patients were compatible with moderate anxiety, and STAI-II scores were compatible with mild anxiety. There was a negative correlation between the age of patients and STAI-I scores $(\mathrm{r}=-0.52$, $\mathrm{p}=0.136)$. and a positive correlation was found between STAI-II and the age of patients $(r=0.22, p=0.321)$. No difference was found in preoperative STAI-I and II scores when evaluated in terms of gender, educational status, history of previous surgery and anesthesia experiences. STAI-I and STAI-II scores were significantly higher in the patients (17.6\%) that thought they didn't have enough information about the pandemic $(\mathrm{p}=0.000, \mathrm{p}=0.001)$. The STAI-I and II scores of the patients with a family history of COVID-19 infection were similar with the other patients $(p=0.76, p=0.91)$. The STAI-I scores of the patients $(287$ patients, 63.8\%) who were worried about being infected with COVID-19 during hospitalization were found to be higher than those who were not afraiding of infected with COVID-19 (163 patients, 36.2\%) ( $\mathrm{p}=0.05)$. There was no patient infected with COVID-19 during hospitalization. Preoperative anxiety levels have increased in patients undergoing elective surgery in COVID-19 pandemic. We think that informing patients about COVID-19 routinely and talking about the precautions to be taken in the preoperative period will be beneficial in reducing their anxiety levels.
\end{abstract}

Key Words: COVID-19. Pandemic. Preoperative anxiety. STAI. 
Geliş Tarihi: 12.Nisan.2021

Kabul Tarihi: 17.Ağustos.2021

Dr. Ayşe Neslihan BALKAYA

Sağlık Bilimleri Üniversitesi,

Bursa Yüksek İhtisas Eğitim ve Araştırma Hastanesi,

Anesteziyoloji ve Reanimasyon Kliniği, Bursa.

Tel.: 05448715343

E-posta: aynesbalkaya@gmail.com

Hastalık, hastaneye yatış, ameliyat kararı gibi durumlar hem psikolojik hem de fizyolojik yönden bireyleri etkiler. Hastaneye yatış ve tedavi durumunda hastalarda \%10-30 oranında anksiyete görülürken cerrahi girişim kararı verilen hastalarda preoperatif dönemde bu oran \%80'e kadar yükselebilmektedir ${ }^{1}$. Anksiyetede korku, endişe, gerginlik ve sinirlilik şeklinde emosyonel bulgular hissedilirken, sempatik, parasempatik ve endokrin sistem etkilendiğinden terleme, bulant1-kusma, ishal, titreme, sicak basması, takipne, taşikardi ve hipertansiyon gibi bulgular gözlenebilir ${ }^{2,3}$. Preoperatif anksiyete düzeyi hastaların kişilik yapılarına bağlı olabileceği gibi geçireceği cerrahi girişimin tipine, önceden geçirilmiş hastalık ve/veya cerrahi işlem deneyimlerine, postoperatif ağrı, sakatlık ya da ölüm korkusu gibi durumlara bağlı olarak değişkenlik gösterir $^{4,5}$.

Aralık 2019 tarihinde Çin'de başlayan ve hızla diğer ülkelere yayılan SARS-CoV-2 enfeksiyonu (COVID19) Dünya Sağlık Örgütü tarafından 11 Mart 2020 tarihinde tüm dünyada pandemi olarak kabul edilmiştir. İnsandan insana hızla bulaşan, özellikle de ciddi solunum yolları tutulumu yapan bu virüs mortal seyredebilmektedir. COVID-19 pandemisinin neden olduğu yüksek ölüm oranları, bulaşma şekli ve tedavisi hakkında net bilgi sahibi olamamak, virüsün kontrol altına alınamaması ve potansiyel risk altında olmak bireylerde korku, endişe yaratmakta ve stres düzeylerini arttırmaktadır. COVID-19 pandemisine karş1 toplumun \%16-28'inde anksiyete ve depresyon semptomlarının olduğu ve bireylerde uyku bozuklukları geliştiği bildirilmektedir ${ }^{6}$.

Ülkemizde de tüm dünyada olduğu gibi pandemi sebebiyle sağlık sisteminde değişiklikler olmuş, elektif cerrahi operasyonlar öncelikle ertelenmiş, vaka sayılarının azalması sonrası, ameliyathanelerde COVID-19 önlemleri alınarak elektif cerrahiler yeniden başlatılmıştır. Çalışmanın hipotezi COVID-19 pandemisinde elektif cerrahi geçirecek hastaların preoperatif anksiyete düzeylerinin artmış olmasıdır. Bu çalışmanın amacı ise pandemi sürecinde elektif cerrahi uygulanacak hastaların preoperatif anksiyete düzeylerinin ve anksiyete seviyelerini etkileyen faktörlerin değerlendirilmesidir.
Yazarların ORCID ID Bilgisi:

Ayşe Neslihan BALKAYA: 0000-0001-8031-6264

Ümran KARACA: 0000-0001-5922-2300

Canan YILMAZ: 0000-0002-6626-3626

Filiz ATA: 0000-0003-2472-1681

\section{Gereç ve Yöntem}

SBÜ Bursa Yüksek İhtisas Eğitim ve Araştırma Hastanesi Etik Kurulu onayı (24/06/2020, 2011-KAEK25) ve hastaların yazılı onamları alınarak 22 Haziran07 Ağustos 2020 tarihlerinde elektif cerrahi geçirecek 18-75 yaş arası, okuma yazma bilen, psikiyatrik hastalığ1 olmayan, psikiyatrik ilaç kullanmayan ve çalışmaya katılmayı kabul eden 450 hasta çalışmaya dahil edildi. Elektif cerrahi uygulanacak hastalar preoperatif dönemde anestezi polikliniğinde ya da cerrahi serviste değerlendirildi. Demografik veriler, medikal geçmiş, anestezi-cerrahi deneyimleri ve COVID-19 hakkında soruların olduğu 15 soruluk anket formu ile Spielberger Durumluk-Sürekli Anksiyete Ölçeği I ve II hastalar tarafindan dolduruldu. 15 soruluk anket formunda COVID ile ilgili hastalığı geçirme, yakalanma korkusu, bilgi düzeyi ile ilişkili sorular yöneltildi.

\section{Spielberger Durumluk- Sürekli Anksiyete Ölçeği (STAI):}

STAI, Spielberger ve arkadaşları tarafından 1970'de geliştirilmiş, Öner ve ark. tarafından 1983'te Türkçe'ye uyarlanarak geçerlilik ve güvenilirlik çalışması yapılmış bir ölçektir ${ }^{7}$. STAI yirmişer maddelik durumluk (STAI-I) ve sürekli (STAI-II) kaygı ölçeklerinden oluşan "Likert tipi kendini değerlendirme" ölçeğidir (b). STAI-I’de anksiyete “(1) hiç, (2) biraz, (3) çok ve (4) tamamıyla" şeklinde puanlanırken, STAI-II'de ise (1) hemen hiçbir zaman, (2) bazen, (3) çok zaman ve (4) hemen her zaman olarak puan almaktadir. STAI'de iki tür ifade bulunur; doğrudan ifadeler olumsuz duyguları, tersine dönmüş ifadeler ise olumlu duyguları gösterir. STAI-I'deki tersine dönmüş ifadeler $1,2,5,8,10,11,15,16,19$ ve 20 . maddelerken STAIII'deki tersine dönmüş ifadeler ise 21,26,27,30,33,36 ve 39 uncu maddelerdir. Doğrudan ifadeler için elde edilen toplam ağırlık puanından ters ifadelerin toplam ağırlık puanı çıkarılır. Elde edilen sonuca değişmeyen bir değer eklenir, bu değer STAI-I için 50, STAI-II için 35'dir. En son elde edilen değer anksiyete puanıdır ve 20-80 arasında değişiklik gösterir. Büyük puan yüksek anksiyete seviyesini, küçük puan ise düşük anksiyete seviyesini belirtir (Tablo I). 
Tablo I. Durumluk Sürekli Kaygı Ölçeği'nin puanına göre kaygı düzeyinin sınıflanması

\begin{tabular}{|c|c|c|}
\hline STAI & Puan & Kaygı Düzeyi \\
\hline & $0-19$ & Kaygı yok \\
& $20-39$ & Hafif düzeyde kaygı \\
& $40-59$ & Orta düzeyde kaygı \\
& $60-79$ & Ağır düzeyde kaygı \\
& $>80$ & Panik düzeyde kaygı \\
\hline
\end{tabular}

STAI: Durumluk Sürekli Kaygı Ölçeği

\section{Istatiksel analiz}

İstatistiksel değerlendirme SPSS 23.0 programı kullanılarak yapıldı. Sayısal değişkenler için tanımlayıc1 istatistikler ortalama \pm standart sapma, kategorik yapıdaki veriler için sayı ve yüzde olarak ifade edildi. Değişkenlerin normal dağılıma uygunluğu Kolmogorov Smirnov Testi ile değerlendirildi. Normal dağılıma uyan değişkenlerin karşılaştırılmasında Student t test, nomal dağılıma uymayan çoklu karşılaştırmalarda Kruskal Wallis testi yapıldı. Bağım11 değişkenlerin analizinde paired samples $\mathrm{t}$ testi kullanıldı. Sonuçlar \%95 güven aralığında değerlendirildi ve $\mathrm{p}<0.05$ değeri anlamlı kabul edildi.

\section{Bulgular}

Çalışmaya yaş ortalaması $49.26 \pm 15.51$ olan toplam 450 hasta katıldı. Hastaların demografik verileri ve eğitim durumları Tablo II'de verildi. Çalışmaya en yoğun olarak Ortopedi ve Travmatoloji $(\% 16,9)$ ile Beyin ve Sinir Cerrahisi (\%14) kliniklerinin hastalarından katılım sağlandı, diğer kliniklerin katılım oranları Tablo III'de verildi.

Tablo II. Hastaların Sosyo-demografik Verileri ve Eğitim Durumlar1

\begin{tabular}{|c|c|}
\hline & $n=450(\%)$ \\
\hline $\begin{array}{rr}\text { Cinsiyet } & \\
& (\mathrm{K} / \mathrm{E}) \\
\end{array}$ & $191 / 259(\% 42.4 / \% 57.6)$ \\
\hline Yaş (yıl) & $49.26 \pm 15.51$ \\
\hline $\begin{array}{r}\text { Kronik hastalık } \\
\text { (Evet/Hayır) }\end{array}$ & $191 / 259(\% 42.4 / \% 57.6)$ \\
\hline $\begin{array}{l}\text { Düzenli ilaç kullanımı } \\
\text { (Evet/Hayır) }\end{array}$ & $189 / 261(\% 42 / \% 58)$ \\
\hline $\begin{array}{r}\text { Sigara tüketimi } \\
\text { (Evet/Hayır) }\end{array}$ & $165 / 285$ (\%36.7 / \%63.3) \\
\hline $\begin{array}{l}\text { Geçirilmiş ameliyat } \\
\text { (Evet/Hayır) }\end{array}$ & $326 / 124(\% 72.4 / \% 27.6)$ \\
\hline $\begin{array}{l}\text { Anestezi tecrübesi } \\
\text { (Evet/Hayır) }\end{array}$ & $317 / 133$ (\%70.4 / \%29.6) \\
\hline $\begin{array}{ll}\text { Eğitim } & \\
& \text { Illkokul } \\
& \text { Ortaokul } \\
& \text { Lise } \\
& \text { Üniversite }\end{array}$ & $\begin{array}{l}223(\% 49.6) \\
100(\% 22.2) \\
77(\% 17.1) \\
50(\% 11.1)\end{array}$ \\
\hline
\end{tabular}

$\mathrm{K}:$ Kadın, E: Erkek, Frekans, ort \pm sd, \%
Tablo III. Cerrahi Klinikler ve Cerrahi Girişim Türleri

\begin{tabular}{|c|c|}
\hline CERRAHI KLINIK & CERRAHI GIRIŞIM TÜRÜ \\
\hline $\begin{array}{l}\text { Ortopedi ve Travmatoloji } \\
(n=76, \% 16.9)\end{array}$ & $\begin{array}{l}\text { implant çıkarımı (12), küçük kemik } \\
\text { cerrahisi (29), büyük kemik cerrahisi } \\
\text { (8), total diz protezi (8), artroskopi } \\
\text { (18), amputasyon (1) }\end{array}$ \\
\hline $\begin{array}{l}\text { Beyin ve Sinir Cerrahisi } \\
(n=63, \% 14)\end{array}$ & $\begin{array}{l}\text { vertebra cerrahisi (48), ventriküloperi- } \\
\text { toneal shunt takılması (3), kraniyoto- } \\
\text { mi (12) }\end{array}$ \\
\hline $\begin{array}{l}\text { Üroloji } \\
(n=89, \% 19.8)\end{array}$ & $\begin{array}{l}\text { perkütan nefrolitotomi (28), üreteros- } \\
\text { kopi (30), transüretral rezeksiyon- } \\
\text { prostat/ mesane (31) }\end{array}$ \\
\hline $\begin{array}{l}\text { Genel Cerrahi } \\
(n=80 \% 17.8)\end{array}$ & $\begin{array}{l}\text { gastrointestinal sistem onkolojik } \\
\text { cerrahi (19), tiroid cerrahisi (4), } \\
\text { laparoskopik kolesistektomi (21), } \\
\text { inguinal-umbilical herni (36) }\end{array}$ \\
\hline $\begin{array}{l}\text { Kardiyovasküler Cerrahi } \\
(\mathrm{n}=81, \% 18.0)\end{array}$ & $\begin{array}{l}\text { kalp kapak cerrahisi (11), koroner } \\
\text { arter bypass greft (57), karotis endar- } \\
\text { terektomi (13) }\end{array}$ \\
\hline $\begin{array}{l}\text { Kadın Hastalıkları ve } \\
\text { Doğum } \\
(n=31, \% 6.9)\end{array}$ & $\begin{array}{l}\text { myomektomi (19), total abdominal } \\
\text { histerektomi + bilateral salpingoofe- } \\
\text { rektomi (12) }\end{array}$ \\
\hline $\begin{array}{l}\text { Diğer branşlar } \\
\text { Göz Hastalıkları } \\
(n=11, \% 2.4) \\
\text { Göğüs Cerrahi }(n=11 \% 2.4) \\
\text { Plastik ve Rekonstrüktif } \\
\text { Cerrahi }(n=8, \% 1.8)\end{array}$ & $\begin{array}{l}\text { vitrektomi (11) } \\
\text { VATS (11) } \\
\text { mammoplasti (8) }\end{array}$ \\
\hline
\end{tabular}

VATS: Video-Assisted Thoracic Surgery

Frekans,\%

Hastaların ortalama anksiyete düzeyi STAI-I'de 41.46 \pm 8.43 , STAI-II'de 37.79 \pm 9.73 olarak bulundu. Opere edilen kliniklere göre hastaların STAI-I puanlar1 orta düzeyde anksiyete ile uyumlu iken STAI-II puanları ise hafif düzeyde anksiyete ile uyumluydu. Beyin ve Sinir Cerrahisi, Göz Hastalıkları, Plastik ve Rekonstrüktif Cerrahi, Gögüs Cerrahi STAI-I ve II puanları arasında fark bulunmazken Ortopedi ve Travmatoloji, Üroloji, Genel Cerrahi, Kardiyovasküler Cerrahi, Kadın Hastalıkları ve Doğum kliniklerinde opere olacak hastaların STAI-I ve II puanları arasında anlamlı fark bulundu $(\mathrm{p}<0.001)$ (Tablo IV).

Tablo IV. Kliniklere göre STAI-I ve STAI-II Puanlarının Karşılaştırılması

\begin{tabular}{|l|c|c|c|}
\hline & STAl-I & STAI-II & $\mathrm{P}$ değeri \\
\hline Ortopedi ve Travmatoloji & $40.08 \pm 7.55$ & $36.67 \pm 9.90$ & $\mathrm{P}=\mathbf{0 . 0 0 2 ^ { * * }}$ \\
\hline Beyin ve Sinir Cerrahisi & $41.19 \pm 7.55$ & $39.50 \pm 9.90$ & $\mathrm{P}=0.108$ \\
\hline Üroloji & $42.13 \pm 9.40$ & $39.08 \pm 10.23$ & $\mathrm{P}=\mathbf{0 . 0 0 0 ^ { * * }}$ \\
\hline Genel Cerrahi & $42.50 \pm 9.12$ & $39.50 \pm 9.00$ & $\mathrm{P}=\mathbf{0 . 0 0 4 ^ { * }}$ \\
\hline Kardiyovasküler Cerrahi & $41.51 \pm 8.24$ & $35.08 \pm 9.44$ & $\mathrm{P}=\mathbf{0 . 0 0 0 ^ { * * }}$ \\
\hline Kadın Hastalıkları ve Doğum & $39.96 \pm 7.99$ & $34.96 \pm 8.08$ & $\mathrm{P}=\mathbf{0 . 0 0 8 ^ { * }}$ \\
\hline Diğer branşlar & $41.26 \pm 8.05$ & $38.60 \pm 9.66$ & $\mathrm{P}=0.185$ \\
\hline
\end{tabular}

STAI, State Trate Anxiety Invantory, Durumluk- Sürekli Anksiyete Ölçeği, Paired- sample test, ort $\pm \mathrm{sd}$, p değeri, *p $<0.05,{ }^{* *} \mathrm{p}<0.001$ 
Hastaların yaşı ile STAI-I arasında negatif yönde korelasyon ( $\mathrm{r}=-0.52, \mathrm{p}=0.136)$, STAI-II'de ise yaş ile pozitif korelasyon saptand $1(\mathrm{r}=0.22, \mathrm{p}=0.321)$. Cinsiyet, geçirilmiş ameliyat öyküsü ve anestezi deneyimi açısından değerlendirildiğinde STAI-I ve II puanlarında farklılık saptanmadı. Çalışmaya en yoğun olarak ilkokul mezunu $(\% 49,6)$ hastaların katıldığı görüldü (Tablo II). Eğitim düzeylerine göre STAI-I ve II puanları karşılaştırıldığında istatistiksel olarak anlamlı fark ve anlamlı bir ilişki saptanmadı. Medikal geçmişinde anestezi ve cerrahi işlem deneyimi olan hastaların STAI-I ve STAI-II puanları deneyimi olmayan hastalarla benzer bulundu. Anestezi deneyiminde sıkıntı (postoperatif şiddetli bulantı-kusma, geç uyanma, anestezik altında farkındalık, zor entübasyon, boğaz ağrısı gibi) yaşayanların STAI-I ve STAI-II puanları sıkıntı yaşamayan hastalarla benzer bulundu.

Tablo V. Cinsiyet, Eğitim Durumu, Medikal Öykü ve COVID-19 Pandemisine Göre STAI-I ve II Puanlarının Karşılaştırılması

\begin{tabular}{|c|c|c|}
\hline & STAI-I & STAI-II \\
\hline Cinsiyet & $\begin{array}{l}41.55 \pm 8.46 \\
41.40 \pm 8.42 \\
p=0.85\end{array}$ & $\begin{array}{l}37.74 \pm 9.71 \\
37.82 \pm 9.70 \\
p=0.93\end{array}$ \\
\hline $\begin{array}{c}\text { Eğitim Durumu } \\
\text { Illkokul } \\
\text { Ortaokul } \\
\text { Lise } \\
\text { Üniversite }\end{array}$ & $\begin{array}{c}42.74 \pm 8.53 \\
40.80 \pm 8.11 \\
39.74 \pm 8.38 \\
39.74 \pm 7.95 \\
p=0.69\end{array}$ & $\begin{array}{c}38.08 \pm 9.98 \\
38.14 \pm 9.22 \\
36.10 \pm 10.07 \\
38.42 \pm 9.05 \\
p=0.47\end{array}$ \\
\hline $\begin{array}{r}\text { Geçirilmiş ameliyat } \\
\text { Evet } \\
\text { Hayır }\end{array}$ & $\begin{array}{l}41.54 \pm 8.55 \\
41.27 \pm 8.11 \\
p=0.75\end{array}$ & $\begin{array}{c}37.67 \pm 10.22 \\
38.11 \pm 8.34 \\
p=0.63\end{array}$ \\
\hline $\begin{array}{r}\text { Anestezi tecrübesi } \\
\text { Evet } \\
\text { Hayır }\end{array}$ & $\begin{array}{l}41.39 \pm 8.62 \\
41.63 \pm 8.00 \\
p=0.78\end{array}$ & $\begin{array}{c}37.86 \pm 10.12 \\
37.61 \pm 8.70 \\
p=0.80\end{array}$ \\
\hline $\begin{array}{c}\text { Anestezi sırasında sıkıntı } \\
\text { Evet } \\
\text { Hayır }\end{array}$ & $\begin{array}{l}44.07 \pm 3.37 \\
41.31 \pm 8.47 \\
p=0.09\end{array}$ & $\begin{array}{l}38.16 \pm 10.00 \\
37.48 \pm 9.60 \\
p=0.63\end{array}$ \\
\hline $\begin{array}{c}\text { COVID-19 için yeterli bilgi } \\
\text { Evet } \\
\text { Hayır }\end{array}$ & $\begin{array}{l}40.84 \pm 8.51 \\
44.63 \pm 7.34 \\
p=0.000^{\star *}\end{array}$ & $\begin{array}{l}37.14 \pm 9.55 \\
40.18 \pm 10.00 \\
p=0.001^{\star *}\end{array}$ \\
\hline $\begin{array}{c}\text { Yakınlarında COVID-19 öyküsü } \\
\text { Evet } \\
\text { Hayır }\end{array}$ & $\begin{array}{l}42.00 \pm 12.12 \\
41.46 \pm 8.38 \\
p=0.91\end{array}$ & $\begin{array}{c}39.14 \pm 11.50 \\
37.77 \pm 9.71 \\
p=0.76\end{array}$ \\
\hline $\begin{array}{c}\text { COVID-19 için sosyal tedirginlik } \\
\text { Evet } \\
\text { Hayır }\end{array}$ & $\begin{array}{l}41.57 \pm 8.28 \\
41.23 \pm 8.70 \\
p=0.68\end{array}$ & $\begin{array}{c}38.05 \pm 9.93 \\
37.23 \pm 9.60 \\
p=0.41\end{array}$ \\
\hline $\begin{array}{l}\text { Hastanede olmanın COVID-19 } \\
\text { tedirginliği } \\
\text { Evet } \\
\text { Hayır }\end{array}$ & $\begin{array}{l}38.44 \pm 9.93 \\
36.63 \pm 9.29 \\
p=0.05^{*}\end{array}$ & $\begin{array}{c}41.56 \pm 8.21 \\
41.30 \pm 8.82 \\
p=0.75\end{array}$ \\
\hline
\end{tabular}

STAI, State Trate Anxiety Invantory, Durumluk- Sürekli Anksiyete Ölçeği, ort $\pm \mathrm{sd}$, p değeri, ${ }^{*} \mathrm{p}<0.05,{ }^{*} \mathrm{p}<0.001$, Student - t Testi, Kruskal Wallis testi
COVID-19 pandemisini güncel olarak takip etmeyen, bu konuda yeterli bilgi sahibi olmadığını düşünen hastaların $(\% 17,6)$ STAI-I ve STAI-II puanları anlamlı yüksekti ( $\mathrm{p}=0.000, \mathrm{p}=0.001) .7$ hastanın ailesi ya da yakınlarında geçirilmiş COVID-19 enfeksiyonu mevcuttu. Bu hastalarda STAI-I 42.0 \pm 12.12 , STAI-II $39.14 \pm 11.50$ olarak bulundu. Ailesinde ya da yakın çevresinde geçirilmiş COVID-19 enfeksiyonu bulunan hastaların STAI-I ve II puanları ile diğer hastaların puanları arasında anlamlı fark yoktu $(\mathrm{p}=0.76, \mathrm{p}=0.91)$. Çalışmaya COVID-19 enfeksiyonu geçirmiş hasta katılımı olmadı. Hastane yatışında COVID-19 ile enfekte olma tedirginliği bulunan hastaların (287 hasta, \%63,8) STAI-I puanı hastanede COVID-19'a yakalanmaktan korkmayanlara (163 hasta, \%36,2) göre yüksek bulundu $(p=0.05)$ (Tablo V). Postoperatif dönemde hastane yatışı sırasında COVID-19 ile enfekte olan hasta olmadi.

\section{Tartışma}

COVID-19 pandemisi sürecinde elektif cerrahi uygulanacak hastaların preoperatif anksiyete düzeylerinin araştırıldığ operatif anksiyete düzeyinde farklılık saptanmadı, tüm hastalarda orta dereceli preoperatif anksiyete olduğu görüldü. COVID-19 pandemisini güncel olarak takip etmeyen, bu konuda yeterli bilgi sahibi olmadığını düşünen hastaların hem durumluk hem de sürekli anksiyete puanları anlamlı yüksek bulundu. Ailesinde ya da yakın çevresinde geçirilmiş COVID-19 enfeksiyonu bulunan hastaların preoperatif anksiyete düzeyinin diğer hastalarla benzer olduğu görüldü. Hastane yatışında COVID-19 ile enfekte olma tedirginliği bulunan hastaların preoperatif anksiyete düzeyi hastanede COVID-19'a yakalanmaktan korkmayanlara göre yüksek bulundu.

Modern cerrahi tekniklerinin gelişmesi ve anestezinin daha güvenli hale gelmesine rağmen cerrahi uygulanacak hastaların çoğu preoperatif dönemde anksiyete yaşar. Preoperatif anksiyete sık görülen, hasta iyileşmesini ve taburculuğu geciktiren, hasta memnuniyetini azaltan bir durumdur ve birçok faktörden etkilenir. Preoperatif anksiyete değerlendirmelerinde en sik STAI ölçeği kullanılmaktadır. STAI-I Durumluk Anksiyete Ölçeği, belirli bir anın stresine bağlı olarak değişebilen anksiyete durumunu, STAI-II Sürekli Anksiyete Ölçeği ise kişinin genel anksiyetesini ve bunu etkileyen kişilik eğilimini yansıtır ${ }^{7,8}$. Çalışmamızda COVID-19 pandemisi sürecinde preoperatif anksiyete düzeyleri STAI ölçeği kullanılarak değerlendirildi. Çalışmamızda hastaların preoperatif durumluk anksiyete düzeyi orta, sürekli anksiyete düzeyi ise hafif olarak bulundu. Preoperatif anksiyete puanları literatürle uyumlu olarak bulundu, hastalarda orta düzeyde preoperatif anksiyete olduğu görüldü ${ }^{8-10}$. 


\section{Pandemide Preoperatif Anksiyete}

Preoperatif anksiyete her yaşta, cinsiyette ve sosyokültürel sınıfta görülebilmektedir ancak cinsiyet, yaş, eğitim durumu ve geçmiş medikal deneyimler hastaların anksiyete seviyelerini etkileyebilmektedir. İlerleyen yaş ile birlikte kazanılan hayat tecrübesi, çıkan sağlık sorunlarına bağlı olarak sağlık kuruluşlarına başvuruda artış olması ileri yaş bireylerde hastalık, cerrahi işlem gereksinimi gibi durumlara adaptasyonun kolay olmasını sağlayabilir. Daha kaderci bir bakış açısına sahip bazı yaşlılar ise hastalık varlığı, cerrahi işlem gereksinimi gibi stresli durumları daha kolay kabul edilebilir ${ }^{11}$. Genç popülasyonda ise iletişim araçlarının daha sık kullanımı ve sağlık alanında yaşanan olumsuz olaylardan haberdar olmaları, iş ve ailelerine karşı daha çok sorumluluk hissetmeleri anksiyetenin yüksek olmasına sebep olabilir ${ }^{12}$. Sun ve ark'larının yaptığı çalışmada 40 yaş altındaki hastalarda preoperatif anksiyete prevalansının arttığ miştir $^{13}$. Bizim çalışmamızda da literatür ile uyumlu olarak yaş ile durumluk anksiyete puanları arasında negatif korelasyon saptand. Hastaların yaşı arttıkça preoperatif dönemde anksiyetenin azaldığı görüldü. İlerleyen yaşla birlikte gelişen fonksiyonel kısıtlılıklar, kronik hastalıklar, bozulmuş yaşam kalitesi, ölüm korkusu, eş-akraba kaybı gibi durumlar arttığı için ileri yaş bireylerde anksiyete artışı gözlenebilir, bizim çalışmamızda da yaş ilerledikçe bireylerde sürekli anksiyetenin arttığ 1 görülmüştür.

Literatürde preoperatif anksiyete düzeyinin cinsiyet ile ilişkisi incelendiğinde, kadınlarda erkeklere göre daha yüksek anksiyete oranlarının olduğu görülmüştür ${ }^{14,15}$. Kadın cinsiyette anksiyete ve depresyon geliştirme riskinin daha yüksek olması ve kadınların korkularını, duygu durum değişikliklerini daha kolay ifade edebilmelerine bağlanır. Bazı çalışmalarda ise cinsiyetin preoperatif anksiyete düzeyini etkilemediği görülmüştür ${ }^{9,12}$. Bizim çalışmamızda da preoperatif anksiyete değerlendirilmesinde cinsiyet açısından fark saptanmamıştır, pandemi sürecinde hastane yatışlarında hastalarda genel olarak yüksek oranda COVID-19 ile enfekte olma korkusu bulunmasının bu durumu açıklayabileceği düşünüldü.

Hastaların eğitim durumları preoperatif anksiyete düzeylerine farklı şekillerde yansıyabilmektedir. Bazı çalışmalarda artan eğitim düzeyi ile birlikte preoperatif anksiyetenin azaldığı bildirilmiştir. Eğitim düzeyi arttıkça insanların daha çok araştıran ve sorgulayan bireyler haline gelerek her konuda daha bilinçli karar verebilecekleri vurgulanmıştır ${ }^{14,16}$. Bunun tersi olarak artan eğitim düzeyi ile birlikte anksiyetenin de arttığını bildiren, bazı konularda detaylı bilgi sahibi olmanın anksiyeteyi arttırabileceğine dikkat çeken çalışmalar bulunmaktadır ${ }^{17,18}$. Ancak eğitim düzeyinin ameliyat öncesi anksiyetenin belirleyicisi olamayacağını bildiren yayınlar da literatürde mevcuttur ${ }^{1,19}$. Çalışmamızda da preoperatif anksiyete ile eğitim düzeyi arasında ilişki saptanmadı. Pandemi sürecinde hastaneye yatış,
COVID-19 maruziyeti korkusu, cerrahi işlem stresi, kişilik özellikleri gibi birçok faktörün bir arada bulunduğu preoperatif dönemde hasta eğitim düzeyinin preoperatif anksiyetenin bağımlı bir değişkeni olmadığı görüldü.

Anestezi ve cerrahi deneyimine sahip olmak hastaların daha rahat bir preoperatif süreç geçirmelerine yardımcı olabilir. Matthias ve ark. yaptıkları çalışmada önceden deneyimi olan hastaların preoperatif dönemde daha az endişeli olduğunu gözlemlemişlerdir ${ }^{14}$. Literatürde anestezi ve cerrahi deneyim öyküsü ile preoperatif anksiyete düzeyi arasında anlamlı ilişkili olmadı $\breve{g}_{1-}$ nı gösteren bazı çalıșmalar da mevcuttur ${ }^{17,20}$. Bu çalışmalara benzer şekilde bizim çalışmamızda da medikal geçmişinde anestezi ve cerrahi deneyimi olan hastalarla deneyim sahibi olmayan hastaların preoperatif anksiyete düzeyleri arasında fark bulunmadı. Kötü anestezi ve cerrahi deneyimler, gelecekteki cerrahi operasyonlarla ilgili daha fazla endişe yaratabilmektedir $^{11,21}$. Çalışmamızda ise medikal öyküsünde kötü anestezi deneyimi bulunan hastaların durumluk anksiyete düzeyleri, kötü deneyim yaşamayan hastalarla benzer bulundu. Hastaların pandemi sürecinde opere olmaları nedeniyle yaşadıkları bulaş-hastalanma korkusu ve anksiyetelerinin, daha önce yaşadıkları kötü medikal deneyimleri önemsizleştirdiği ya da bu durumu yadsımalarına neden olduğu düşünüldü.

Ameliyat tipi ve ameliyat edecek klinik preoperatif anksiyetenin bir belirleyicisi olarak tanımlanabilir. Literatürde preoperatif anksiyete ve cerrahi prosedürün büyüklüğü ile ilişkili birçok çalışma yapılmış$\operatorname{tır}^{9,15,22,23}$. Cerrahi prosedürün büyüklüğü ve invazivliği arttıkça hastalarda preoperatif anksiyete düzeylerinde artış olduğu saptanmıştır. Cerrahi prosedürlerin sınıflandirılması, prosedürün uzunluğu, dahil edilen organ ve dokular, cerrahi kan kaybı, cerrahi nedeniyle hastanede kalış süresi gibi çeşitli özellikleri hesaba katar ancak cerrahi prosedürlerin invazifliğine ilişkin tek tip, uluslararası olarak onaylanmış bir sınıflandırma yoktur. $\mathrm{Bu}$ sebeple çalışmamızda kliniklere göre cerrahi prosedürlerin büyüklüğü sınıflandırılmamış, sadece kliniklere göre hasta dağılımı yapılarak preoperatif anksiyete bakılmıştır bu da çalışmamızın sınırlılıkları arasında yer almaktadır.

Postoperatif ağrı insidansının fazla olması ve hastalarda postoperatif sakatlık korkusundan dolayı ortopedik cerrahi geçirecek hastalarda preoperatif anksiyete yüksektir ${ }^{24}$. Yapılan bazı çalışmalarda major girişim planlanan kardiyovasküler cerrahi hastalarında anksiyete sıklığı yüksek bulunmuştur, bu durumun kardiyak sebepli potansiyel ölüm korkusundan olduğu düşünülmektedir ${ }^{24-26}$. Literatürde batın cerrahisi, ürogenital cerrahi, onkolojik cerrahi, toraks cerrahisi geçiren olgularda preoperatif anksiyete düzeyleri yüksek bulunmuştur ${ }^{8,24,27,28}$. Kindler ve ark.' larının çalışmasında beyin ve sinir cerrahisi olgularında preoperatif anksiyete düzeyleri diğer branşlardan düşük saptanmıştır ${ }^{28}$. 
Literatürde jinekolojik ve obstetrik cerrahi geçirenlerde anksiyete düzeyi yüksek saptanmış ve bu durum sadece kadın cinsiyetle ilgili bir branş olmasına bağlanmıştır $^{20,24}$. Çalışmamızda cerrahi kliniklere göre preoperatif anksiyete düzeyinde farklılık saptanmadı. Tüm hastalarda orta dereceli preoperatif anksiyete ve hafif düzeyde sürekli anksiyete olduğu görüldü. Beyin ve sinir cerrahisi, göz hastalıkları, plastik ve rekonstrüktif cerrahi, gögüs cerrahisi hastaları hariç çalışmaya katılan diğer kliniklerin hastalarında durumluk anksiyete ile sürekli anksiyete arasında fark görüldü, bu branşlardaki hastalarda preoperatif süreçte anksiyete düzeyleri istatistiksel açıdan anlamlı düzeyde arttı. Plastik ve rekonstrüktif cerrahide mammoplasti uygulanacak hastalarda isteğe bağlı, estetik kaygıyla da ilişkilendirilebilecek bir işlem yapılacak olması sebebiyle durumluk anksiyete ile sürekli anksiyete skorları arasında fark görülmediği düşünüldü. Göz hastalıklarında opere olacak hastaların ise gözü lokal bir organ olarak algılaması ve cerrahi riskin daha düşük olduğunu düşünmeleri sebebiyle preoperatif anksiyetede belirgin artış yaşanmadığı düşünüldü. Preoperatif durumluk anksiyete ile sürekli anksiyete düzeyleri arasında farka rastlanmayan hastalarda bu durum hastaların kişilik yapılarına ve psikolojik durumlarına bağlı olabilir.

COVID-19 pandemisi, yaşamın her yönünü etkileyen ve sosyal dokuyu bozan ciddi etiyolojik, küresel bir sorun oluşturmuştur. Bireyler pandemiler sırasında değişen düzeylerde psikolojik sıkıntı yaşarlar ve bu durum yaygın olarak korku, stres, uyku bozuklukları ve anksiyete şeklinde görülür. Korukçu ve ark’larının COVID-19 Korku Ölçeği kullanarak yaptıkları psikometrik çalışmada Türkiye'de COVID-19 için korku düzeyi yüksek bulunmuştur ${ }^{29}$. Satıcı ve ark'larının yaptıkları çalışmada ise Türkiye'de COVID-19 ile enfekte olma korkusu ile anksiyete ve depresyon gelişimi arasında pozitif korelasyon olduğu bildirilmiştir ${ }^{30}$. Bizim çalışmamızda kendi sosyal çevrelerinde enfekte olmaktan korkan ve korkmayan hastaların hem durumluk hem de sürekli anksiyete puanları benzer bulundu. Hastaneye yatışta COVID-19 ile enfekte olma korkusu duyanların durumluk anksiyete puanları enfekte olmaktan korkmayan hastalardan yüksekti. Hastane yatışı sırasında COVID-19 ile enfekte olma konusunda endişelenmek, hastaların hiçbiri enfekte olmamasına rağmen, preoperatif dönem durumluk anksiyete düzeyi için güçlü bir faktördür. Hastanelerin hem normal işleyişine devam etmesi hem de COVID19'lu hastalara bakım vermesi sebebiyle hastaneye yatış COVID-19 bulaşı açısından yüksek risk taşımaktadır. Bu sebeple hastanede yatış sürecinde COVID-19 bulașına dair korku, preoperatif dönemde hastalarda yoğun anksiyete yaratabilmektedir.

Toplumda COVID-19 hakkında bilgi düzeylerinin arttırılması ile bireylerin anksiyete düzeylerinde azalma sağlanabilir. Rakhmanov ve ark'ları yaptıkları çalışmada COVID-19 ile ilgili bilgi düzeyi arttıkça anksiyete düzeyinde azalma olduğunu bildirmişlerdir ${ }^{31}$. Liu ve ark'larının çalışmasında da prenatal dönemde hamile kadınlarda COVID-19 ile ilgili bilgi düzeyinin artmasının anksiyeteyi azalttığı saptanmıştır ${ }^{32}$. Bizim çalışmamızda da COVID-19 hakkında yeterli bilgi sahibi olmayan, güncel durumu takip etmeyen hastalarda hem durumluk hem de sürekli anksiyete puanları pandemi sürecini takip ederek bilgi sahibi olanlara göre yüksek bulundu. Çalışmamızda COVID-19 hakkında güncel haberlerin, verilerin takip edilmesinin ve toplumda bilgi düzeyindeki artışın preoperatif anksiyete düzeyini azalttığ 1 görülmüştür. Küresel bir sorun olan COVID-19 pandemisi uluslararası bir halk sağlı̆̆ sorunudur. COVID-19 pandemisinde toplumun büyük kısmının sosyal izolasyon ve karantina sürecinde olduğu düşünüldüğünde toplumsal bilgilendirmede medya önemli bir rol almıştır. Medyada net ve anlaş1lır olarak hastalığın seyri, bulaş şekli, korunma yolları, tedavi şekli gibi bilgilerin verilmesi ile toplumsal anksiyetede azalma sağlanabilir. Hastaneye başvurularda ise sağlık personellerinin COVID-19 hakkında hastalara net ve anlaşılır bilgi vermesi önemlidir. Özellikle hastaların COVID-19 dışındaki sebeplerle hastane başvurularında hastalar için koruyucu hekimlik ön plana çıkmalı, hasta bilgilendirmeleri daha kapsamlı olarak yapılmalıdır.

\section{Sonuç}

Elektif cerrahi geçirecek hastalarda COVID-19 pandemisi döneminde preoperatif anksiyete düzeyleri artmıştır. Hastaların preoperatif anksiyete düzeylerinin belirlenerek ilerleyen dönemde anksiyeteyi azaltmak için yeni stratejilerin geliştirilmesi gerekmektedir. Çalışmamızda COVID-19 ile ilgili yetersiz ya da eksik bilgisi olan hastaların preoperatif anksiyete düzeyinin daha fazla olmasindan dolayı preoperatif dönemde hastalara COVID-19 ile ilgili rutin bilgilendirme yapılmasının, ameliyathane ve servislerde al1nacak önlemlerden bahsedilmesinin anksiyete düzeyini azaltmada faydalı olacağı düşüncesindeyiz.

\section{Etik Kurul Onay Bilgisi:}

Onaylayan Kurul: Bursa Yüksek İhtisas Eğitim ve Araştırma Hastanesi, Klinik Araştırmalar Etik Kurulu.

Onay Tarihi: 24.06 .2020

Karar No: 2011-KAEK-25 2020/06-20

Arastırmacı Katkı Beyanı: Fikir ve tasarım: A.N.B., C.Y.; Veri toplama ve işleme: A.N.B., F.A., Ü.K.; Analiz ve verilerin yorumlanması: A.N.B., Ü.K., C.Y.; Makalenin önemli bölümlerinin yazılması: A.N.B., C.Y., F.A.

Destek ve Teşekkür Beyanı: Çalışmamızda herhangi bir finansal destek alınmamıştır.

Çıkar Çatışması Beyanı: Makale yazarının çıkar çatışması beyanı yoktur. 


\section{Kaynaklar}

1. Mingir T, Ervatan Z,Turgut N. Spinal anaesthesia and perioperative anxiety. Turk J Anaesth Reanim 2014; 42: 190-5. https://doi.org/10.5152/TJAR.2014.99705.

2. Jlala HA, French JL, Foxall GL, Hardman JG, Bedforth NM. Effect of preoperative multimedia information on perioperative anxiety in patients undergoing procedures under regional anaesthesiology. $\quad \mathrm{Br} \quad \mathrm{J} \quad$ Anaesth 2010;104:369-74. https://doi.org/10.1093/ bja /aeq002.

3. Sigdel S. Perioperative anxiety: a short review. Glob Anaesth Perioper Med. 2015;1(4): 107-108. https://doi.org/10.15761 /GAPM.1000126.

4. Erkilic E, Kesimci E, Soykut C, Doger C, Gumus T, Kanbak O Factors associated with preoperative anxiety levels of Turkish surgical patients: from a single center in Ankara. Patient Prefer Adher. 2017;11:291-6. https://doi.org/10.2147/PPA.S127342.

5. Badner NH, Nielson WR, Munk S, Kwiatkowska C, Gelb AW. Preoperative anxiety: Detection and contributing factors. Can J Anaesth 1990; 37: 444-7.

6. Rajkumar RP. COVID-19 and mental health: A review of the existing literature. Asian J Psychiatr. 2020;52:102066 https://doi.org/10.1016/j.ajp.2020.102066.

7. Spielberger C. State-trait anxiety inventory: a comprehensive bibliography. 1989, Palo Alto, CA, Mind Garden. pp 4-12.

8. Karadağ ŞA. Ameliyat Öncesi Anksiyetenin APAIS ve STAI-I Ölçekleri İle Değerlendirilmesi. Hacettepe Üniversitesi Hemşirelik Fakültesi Dergisi. 2018; 4(3): 38-47.

9. Demir A, Akyurt D, Ergün B, et al. Anxiety therapy in cardiac surgery patients. Turkish J Thorac Cardiovasc Surg. 2010;18(3):177-82.

10. Domar AD, Everett LL, Keller MG. Preoperative anxiety: Is it a predictable entity? Anesth Analg. 1989;69: 763-67.

11. Shevde K, Panagopoulos G. A survey of 800 patients knowledge, attitudes, and concerns regarding anesthesia. Anesth Analg. 1991; 73: 190-98.

12. Won K, Gyeong B, Bong S, Hyeon L. Availability of preoperative anxiety scale as a predictive factor for hemodynamic changes during induction of anesthesia. Korean J. Anesthesiol. 2010;58:328-33, https://doi.org/10.4097/kjae.2010. 58.4.328.

13. Sun GC, Hsu MC, Chia YY, Chen PY, Shaw FZ. Effects of age and gender on intravenous midazolam premedication: a randomized double-blind study. Br J Anaesth. 2008;101:632-39. https://doi.org/10.1093 / bja / aen251.

14. Matthias AT, Samarasekera DN. Preoperative anxiety in surgical patients-experience of a single unit. Acta Anaesthesiol Taiwanica. 2012;50(1):3-6. https://doi.org/10.1016/ j.aat. 2012.02.004.

15. Perks A, Chakravarti S, Manninen P. Preoperative anxiety in neurosurgical patients. J Neurosurg Anesthesiol. 2009;21 (2):127-30.

16. Mulugeta et al. Preoperative anxiety and associated factors among adult surgical patients in Debre Markos and Felege Hiwot referral hospitals, Northwest Ethiopia BMC Anesthesiology. 2018;18:155. https://doi.org/10.1186/12871-018-0619-0.

17. Nigussie S, Belachew T, Wolancho W. Predictors of preoperative anxiety among surgical patients in Jimma University speci- alized teaching hospital, South Western Ethiopia. BMC Surg. 2014;14(1):1. https://doi.org/10.1186/1471-2482-14-67.

18. Yilmaz M, Sezer H, Gürler H, Bekar M. Predictors of preoperative anxiety in surgical inpatients. J Clin Nurs. 2012;21(78):956-64.

19. Wells JK, Howard GS, Nowlin WF, Vargas MJ. Presurgical anxiety and postsurgical pain and adjustment: effects of a stress inoculation procedure. J Consult Clin Psychol. 1986;54(6):83135.

20. Jafar MF, Khan FA. Frequency of preoperative anxiety in Pakistani surgical patients. JPMA. 2009;59(6):359-63.

21. Wang TF, Wu YT, Tseng CF, Chou C. Associations between dental anxiety and postoperative pain following extraction of horizontally impacted wisdom teeth. Medicine; 2017;96(47): 8665. https://doi.org/10.1097/MD.0000000000008665.

22. Navarro-Gastón D, Munuera-Martínez PV. Prevalence of preoperative anxiety and its relationship with postoperative pain in foot nail surgery: A cross-sectional study. Int J Environ Res Public Health. 2020;22;17(12):4481. https://doi.org/10.3390/ijerph17124481.

23. Caumo W, Schmidt AP, Schneider CN, Bergmann J, Iwamoto CW, Bandeira D, Ferreira MB. Risk factors for preoperative anxiety in adults. Acta Anaesthesiol Scand. 2001;45(3):298307.

24. Nomura M, Saeki S, Ogawa S, Tai K, Kajiwara K. Preoperative questionnaire survey about anxiety of patients for scheduled operation Masui. The Japanese Journal of Anesthesiology. 2000;49(8):913-19.

25. Tully PJ, Baker AR, Winefield HR, Turnbull DA. Depression, anxiety disorders and Type D personality as risk factors for delirium after cardiac surgery. Aust NZJ Psychiatry. 2010;44(11):1005-11.

26. Krannich JH, Weyers P, Lueger S, Herzog M, Bohrer T, Elert O. Presence of depression and anxiety before and after coronary artery bypass graft surgery and their relationship to age. BMC Psychiatry. 2007;7:47.

27. Arslan S, Ozer N, Ozyurt F. Effect of music on preoperative anxiety in men undergoing urogenital surgery. AJAN. 2008;26(2), 46-54.

28. Kindler CH, Harms C, Amsler F, Ihde-Scholl T, Scheidegger D. The visual analogue scale allows effective measurement of preoperative anxiety and detection of patient's 2000;90:706-12. https://doi.org/10.1097/ 00000539-200003000-00036.

29. Korukcu O, Ozkaya M, Boran OF, Boran M. The effect of the COVID-19 pandemic on community mental health: A psychometric and prevalence study in Turkey. Health Soc Care Community. 2020;00:1-10. https://doi.org/10.1111/hsc.13270.

30. Satici B, Gocet TE, Deniz ME, Satici SA. Adaptation of the fear of COVID-19 scale: its association with psychological distress and life satisfaction in Turkey. Int J Ment Health Addict. 2020(5); 8:1-9. https://doi.org/10.1007/s11469-020-00294-0333.

31. Rakhmanov O, Dane S. Knowledge and anxiety levels of African university students against COVID-19 during the pandemic outbreak by an online survey. Int Dent J. 2020;8:53-6.

32. Liu X, Chen M, Wang Y, Sun L, et all. Prenatal anxiety and obstetric decisions among pregnant women in Wuhan and Chongqing during the COVID-19 outbreak: a cross-sectional study. BJOG. 2020(9);10, 1229-40. https://doi.org/10.1111 / 1471-0528.16381. 
